\title{
Humanitarian evidence and discourse summary No.23
}

\author{
Luke Kelly \\ University of Manchester \\ February 2022
}

Monthly Humanitarian Evidence and Discourse Summaries aim to signpost FCDO and other UK government departments to the latest relevant evidence and discourse on humanitarian action. It is structured around three themes:

- Protect: Protect civilians, IDPs, refugees, marginalised groups including women and girls, and humanitarian access.

- Prioritise: Prioritise effective humanitarian assistance to people in greatest need

- Prevent: Prevent and anticipate future shocks and rebuild resilience in protracted and recurring crises

Further detail on methodology, scope and resource hubs at the end. Click on the following hyperlinks to bring you down to the relevant literature.

\section{Protect}

\begin{tabular}{|c|c|c|c|c|}
\hline $\begin{array}{l}\text { Publication } \\
\text { date }\end{array}$ & Title/URL & $\begin{array}{l}\text { Publication type (evidence, } \\
\text { discourse or policy/guidance) }\end{array}$ & Summary & $\begin{array}{l}\text { HoP } \\
\text { Top } \\
\text { reads }\end{array}$ \\
\hline $\begin{array}{l}\text { January } \\
2022\end{array}$ & $\begin{array}{l}\text { Life and Death: } \\
\text { NGO access to } \\
\text { financial services } \\
\text { in Afghanistan }\end{array}$ & $\begin{array}{l}\text { Erica Moret; Norwegian } \\
\text { Refugee Council } \\
\text { Evidence } \\
\end{array}$ & $\begin{array}{l}\text { The report shows the significant } \\
\text { difficulties faced by humanitarian } \\
\text { organisations in transferring funds to } \\
\text { Afghanistan. It maps out } 12 \text { types of } \\
\text { payment channel and assesses their } \\
\text { risks, reliability, cost and capacity. } \\
\text { They are: public and private banks, } \\
\text { the Afghan postal service, Money } \\
\text { transfer operators, money service } \\
\text { businesses, informal systems, the UN } \\
\text { humanitarian finance corridor, } \\
\text { currency swaps and digital platforms. } \\
\text { It finds that no channel is able to send } \\
\text { sufficient funds for Afghanistan's } \\
\text { humanitarian needs. }\end{array}$ & \\
\hline $\begin{array}{l}28 \text { January } \\
2022\end{array}$ & $\begin{array}{l}\text { Delivering digital } \\
\text { aid when the } \\
\text { internet becomes } \\
\text { a weapon of war }\end{array}$ & $\begin{array}{l}\text { Catherine Cheney; Devex } \\
\text { Discourse }\end{array}$ & $\begin{array}{l}\text { Article on the risks of cyber attacks to } \\
\text { humanitarian action and how } \\
\text { humanitarians can respond. } \\
\text { Discusses calls for 'digital } \\
\text { humanitarian space' and that the } 2019 \\
\text { reviews of the Geneva Conventions } \\
\text { did not improve digital protections. } \\
\text { Humanitarian actors need to build } \\
\text { contingency plans to work round data } \\
\text { butages and invest in data security. }\end{array}$ & \\
\hline
\end{tabular}




\begin{tabular}{|c|c|c|c|}
\hline $\begin{array}{l}17 \text { January } \\
2022\end{array}$ & $\begin{array}{l}\text { Make the sky safe } \\
\text { again: Ending } \\
\text { impunity for drone } \\
\text { attacks in Tigray }\end{array}$ & $\begin{array}{l}\text { Meron Gebreananaye et al.; } \\
\text { World Peace Foundation } \\
\text { Discourse }\end{array}$ & $\begin{array}{l}\text { Blog on the killing of civilians by } \\
\text { drones, and curtailment of } \\
\text { humanitarian aid in some regions of } \\
\text { Ethiopia. The media blackout makes it } \\
\text { difficult to assess the full extent of the } \\
\text { problem. Argues that law on these } \\
\text { weapons should be clarified, and } \\
\text { states should take steps to prevent } \\
\text { drones being sent to Ethiopia. }\end{array}$ \\
\hline $\begin{array}{l}13 \text { January } \\
2022\end{array}$ & $\begin{array}{l}\text { Shaping United } \\
\text { States policy and } \\
\text { practice on the } \\
\text { protection of } \\
\text { civilians }\end{array}$ & $\begin{array}{l}\text { Victoria Metcalfe-Hough; ODI } \\
\text { Evidence }\end{array}$ & $\begin{array}{l}\text { Briefing note on the evolution of the } \\
\text { Protection of Civilians Working Group } \\
\text { that has sought to influence the US for } \\
\text { petter protection of civilians outcomes. }\end{array}$ \\
\hline $\begin{array}{l}20 \text { January } \\
2022\end{array}$ & $\begin{array}{l}\text { Shifting the } \\
\text { narrative: not } \\
\text { weapons, but } \\
\text { technologies of } \\
\text { warfare }\end{array}$ & $\begin{array}{l}\text { Klaudia Klonowska; ICRC Law } \\
\text { \& Policy blog } \\
\text { Discourse }\end{array}$ & $\begin{array}{l}\text { Argues that not just weapons should } \\
\text { be considered in the regulation of war. } \\
\text { Technologies such as Al have } \\
\text { significant effects in conflict, but many } \\
\text { focus narrowly on a 'weapons review' } \\
\text { when considering IHL obligations. } \\
\text { Based on obligations under AP1 of the } \\
\text { Geneva Conventions, states should } \\
\text { include technologies that influence } \\
\text { wars, directly or indirectly. }\end{array}$ \\
\hline $\begin{array}{l}2 \text { February } \\
2022\end{array}$ & $\begin{array}{l}\text { Externalization } \\
\text { and the Global } \\
\text { Compact on } \\
\text { Refugees: } \\
\text { Responsibility } \\
\text { Shifting and the } \\
\text { role of the EU }\end{array}$ & $\begin{array}{l}\text { Webinar; ASILE } \\
\text { Discourse }\end{array}$ & $\begin{array}{l}\text { Discussion on the relationship } \\
\text { between European refugee } \\
\text { externalisation policies and the Global } \\
\text { Compact on Refugees. }\end{array}$ \\
\hline $\begin{array}{l}25 \text { January } \\
2022\end{array}$ & $\begin{array}{l}\text { Explosive } \\
\text { weapons with } \\
\text { wide area effects: } \\
\text { a deadly choice in } \\
\text { populated areas }\end{array}$ & $\begin{array}{l}\text { Eirini Giorgou; ICRC Law \& } \\
\text { Policy blog } \\
\text { Evidence } \\
\end{array}$ & $\begin{array}{l}\text { While there is 'no general prohibition } \\
\text { in IHL on the use of explosive } \\
\text { weapons with a wide impact area in } \\
\text { populated areas', rules on } \\
\text { proportionality and indiscriminate } \\
\text { killing do apply. The blog argues that it } \\
\text { is difficult to use such weapons in } \\
\text { populated areas without causing } \\
\text { unacceptable civilian harm, and calls } \\
\text { on states to impose limitations on their } \\
\text { use. }\end{array}$ \\
\hline $\begin{array}{l}\text { January } \\
2022\end{array}$ & $\begin{array}{l}\text { Guidance on } \\
\text { bureaucratic and } \\
\text { administrative } \\
\text { impediments (BAI) }\end{array}$ & $\begin{array}{l}\text { Interagency Standing } \\
\text { Committee (IASC) Results } \\
\text { Group } 1 \text { on Operational } \\
\text { Response } \\
\text { Policy/guidance }\end{array}$ & $\begin{array}{l}\text { Proposes a five-point strategy for } \\
\text { dealing with BAI in a collective manner } \\
\text { through: } \\
\text { 1) A common understanding of the } \\
\text { drivers and impacts of BAl } \\
\text { 2) Strengthened coordination to } \\
\text { address the operational impacts } \\
\text { 3) Preventing BAl through } \\
\text { monitoring and early action } \\
\text { 4) Collective and strategic advocacy } \\
\text { 5) Mobilise global support for action }\end{array}$ \\
\hline
\end{tabular}




\section{Prioritise}

\begin{tabular}{|c|c|c|c|c|}
\hline $\begin{array}{l}\text { Publication } \\
\text { date }\end{array}$ & Title/URL & $\begin{array}{l}\text { Publication type (evidence, } \\
\text { discourse or policy/guidance) }\end{array}$ & Summary & Top \\
\hline $\begin{array}{l}\text { January } \\
2022\end{array}$ & $\begin{array}{l}\text { Sharing to } \\
\text { Survive: } \\
\text { Investigating the } \\
\text { Role of Social } \\
\text { Networks During } \\
\text { Yemen's } \\
\text { Humanitarian } \\
\text { Crisis }\end{array}$ & $\begin{array}{l}\text { J. Kim et al.; Resilience } \\
\text { Evaluation, Analysis and } \\
\text { Learning (REAL) } \\
\text { Evidence }\end{array}$ & $\begin{array}{l}\text { Analysis of the use of social } \\
\text { connections for support by Yemeni } \\
\text { households. It shows the importance of } \\
\text { remittances from abroad, as well as } \\
\text { the obligations to share, and how these } \\
\text { are shaped by kinship, politics, } \\
\text { location, class, gender and other } \\
\text { factors. The length of the war and } \\
\text { Covid measures have limited the role } \\
\text { of sharing. It also gives } \\
\text { recommendations on how outside } \\
\text { actors can take networks into } \\
\text { consideration to avoid elite capture, or } \\
\text { the marginalisation of some groups. }\end{array}$ & \\
\hline $\begin{array}{l}\text { January } \\
2021\end{array}$ & $\begin{array}{l}\text { A Red Cross Red } \\
\text { Crescent guide to } \\
\text { community } \\
\text { engagement and } \\
\text { accountability }\end{array}$ & $\begin{array}{l}\text { Red Cross and Red Crescent } \\
\text { Policy/guidance }\end{array}$ & $\begin{array}{l}\text { Seven modules on community } \\
\text { engagement and accountability, from } \\
\text { the level of emergency response to the } \\
\text { organisational level. }\end{array}$ & \\
\hline $\begin{array}{l}\text { December } \\
2021\end{array}$ & $\begin{array}{l}\text { Humanitarian Aid } \\
\text { on the Move No. } \\
23\end{array}$ & $\begin{array}{l}\text { Groupe URD } \\
\text { Evidence }\end{array}$ & $\begin{array}{l}\text { Special issue on how traditional } \\
\text { humanitarian actors can work with } \\
\text { organisations practising local solidarity. } \\
\text { Authors discuss best practice for such } \\
\text { partnerships, examples from CCFD- } \\
\text { Terre Solidaire and Action contra la } \\
\text { Faim, and a bibliography on } \\
\text { localisation. }\end{array}$ & \\
\hline $\begin{array}{l}14 \text { January } \\
2022\end{array}$ & $\begin{array}{l}\text { Blockchain } \\
\text { humanitarianism } \\
\text { and crypto- } \\
\text { colonialism }\end{array}$ & Discourse & $\begin{array}{l}\text { This opinion piece argues that } \\
\text { blockchain projects 'principally serve a } \\
\text { public-relations (PR) function for the } \\
\text { broader crypto-economy and extend } \\
\text { colonial legacies of experimentation in } \\
\text { the developing world'. }\end{array}$ & \\
\hline $\begin{array}{l}26 \text { January } \\
2022\end{array}$ & $\begin{array}{l}\text { Rethinking } \\
\text { Humanitarianism: } \\
\text { An interview with } \\
\text { the UN's } \\
\text { humanitarian chief }\end{array}$ & $\begin{array}{l}\text { Heba Aly and Martin Griffiths; } \\
\text { Rethinking Humanitarianism } \\
\text { podcast } \\
\text { Discourse }\end{array}$ & $\begin{array}{l}\text { Discussion of Griffiths' aims as Under- } \\
\text { Secretary-General for humanitarian } \\
\text { affairs, including debates on power } \\
\text { imbalances in the sector, the influence } \\
\text { of donors, conflict resolution, and } \\
\text { others. }\end{array}$ & \\
\hline $\begin{array}{l}\text { November } \\
2021\end{array}$ & $\begin{array}{l}\text { Drowning just } \\
\text { below the surface: } \\
\text { The } \\
\text { socioeconomic } \\
\text { consequences of } \\
\text { the COVID-19 } \\
\text { pandemic }\end{array}$ & $\begin{array}{l}\text { ICRC/IFRC } \\
\text { Evidence } \\
\text { (3) }\end{array}$ & $\begin{array}{l}\text { Global overview of the socio-economic } \\
\text { impacts of Covid- } 19 .\end{array}$ & \\
\hline $\begin{array}{l}\text { January } \\
2022\end{array}$ & $\begin{array}{l}\text { Analysing } \\
\text { Intersecting Social } \\
\text { Inequalities in } \\
\text { Crisis Settings }\end{array}$ & $\begin{array}{l}\text { Becky Carter; K4D } \\
\text { Evidence } \\
\text { ? }\end{array}$ & $\begin{array}{l}\text { Summarises relevant analytical } \\
\text { frameworks on intersecting social } \\
\text { inequalities in crisis settings. The } \\
\text { appendix includes } 12 \text { frameworks from } \\
\text { NGOs and international organisations } \\
\text { and the review highlights key themes } \\
\text { in the frameworks and good practice. }\end{array}$ & \\
\hline
\end{tabular}




\begin{tabular}{|c|c|c|c|c|}
\hline $\begin{array}{l}\text { December } \\
2021\end{array}$ & $\begin{array}{l}\text { Localization: A } \\
\text { "Landscape" } \\
\text { Report }\end{array}$ & $\begin{array}{l}\text { Sabrina Robillard, Teddy Atim } \\
\text { and Daniel Maxwell; Feinstein } \\
\text { International Center } \\
\text { Evidence }\end{array}$ & $\begin{array}{l}\text { A literature review and interviews on } \\
\text { understandings of the term localisation. } \\
\text { It notes different conceptions of } \\
\text { localisation, and identifies key barriers } \\
\text { such as power structures and capacity } \\
\text { challenges. It includes } \\
\text { recommendations for institutional } \\
\text { donors. }\end{array}$ & \\
\hline $\begin{array}{l}\text { January } \\
2022\end{array}$ & $\begin{array}{l}\text { Localisation Re- } \\
\text { imagined: Regene } \\
\text { rating the } \\
\text { polyculture of } \\
\text { humanitarianism }\end{array}$ & $\begin{array}{l}\text { Arbie Baguios; ALNAP } \\
\text { Discourse }\end{array}$ & $\begin{array}{l}\text { The third in a series of five blogs looks } \\
\text { at the role of local and national actors, } \\
\text { using evidence from Myanmar, } \\
\text { Colombia and the private sector. }\end{array}$ & \\
\hline $\begin{array}{l}6 \text { January } \\
2022\end{array}$ & $\begin{array}{l}\text { Accountability is } \\
\text { about leadership, } \\
\text { not mechanisms. } \\
\text { Why we need to } \\
\text { stop 'doing' AAP }\end{array}$ & $\begin{array}{l}\text { Nick van Praag and Meg } \\
\text { Sattler; Ground Truth } \\
\text { Solutions } \\
\text { Discourse }\end{array}$ & $\begin{array}{l}\text { A short blog that argues that despite } \\
\text { the prevalence of accountability to } \\
\text { affected people (AAP) work, many aid } \\
\text { recipients do not get the aid they need } \\
\text { the most. They argue that longer } \\
\text { programme cycles, independent } \\
\text { evidence on humanitarian } \\
\text { performance, and identifying and } \\
\text { overcoming barriers to AAP. }\end{array}$ & \\
\hline $\begin{array}{l}\text { January } \\
2022\end{array}$ & $\begin{array}{l}\text { A method for small- } \\
\text { area estimation of } \\
\text { population mortality } \\
\text { in settings affected } \\
\text { by crises }\end{array}$ & $\begin{array}{l}\text { Francesco Checchi et al.; } \\
\text { Population Health Metrics } \\
\text { Evidence }\end{array}$ & $\begin{array}{l}\text { Describes a 'small-area estimation' } \\
\text { method to estimate mortality in areas } \\
\text { where demographic surveillance is } \\
\text { lacking. It is based on 'data previously } \\
\text { collected by national and humanitarian } \\
\text { actors'. The method is described in six } \\
\text { steps, and examples of use in Somalia, } \\
\text { South Sudan and Nigeria are given. }\end{array}$ & \\
\hline $\begin{array}{l}\text { January } \\
2022\end{array}$ & $\begin{array}{l}\text { Adolescent } \\
\text { Refugee Girls' } \\
\text { Secondary } \\
\text { Education in } \\
\text { Ethiopia: An } \\
\text { Empirical Analysis } \\
\text { of Multiple } \\
\text { Vulnerabilities in } \\
\text { Low-Resource } \\
\text { Displacement } \\
\text { Settings }\end{array}$ & $\begin{array}{l}\text { Shelley Carvalho; Center for } \\
\text { Global Development } \\
\text { Evidence }\end{array}$ & $\begin{array}{l}\text { Analysis of the disadvantages affecting } \\
\text { refugee girls and host communities in } \\
\text { Ethiopia, based on household surveys, } \\
\text { with implications for humanitarian } \\
\text { targeting. }\end{array}$ & \\
\hline $\begin{array}{l}26 \text { January } \\
2022\end{array}$ & $\begin{array}{l}\text { Innovation for } \\
\text { Sexual and } \\
\text { Reproductive } \\
\text { Health in } \\
\text { Humanitarian } \\
\text { Crises Where we } \\
\text { are now and how } \\
\text { to move the } \\
\text { agenda forward }\end{array}$ & $\begin{array}{l}\text { Kimberley Popple et al.; } \\
\text { ELHRA } \\
\text { Policy/guidance }\end{array}$ & $\begin{array}{l}\text { The paper assesses the status of SRH } \\
\text { programmes and areas where } \\
\text { innovation could help across the } \\
\text { humanitarian sector. It discusses the } \\
\text { concept of innovation and maps SRH } \\
\text { innovations. }\end{array}$ & \\
\hline $\begin{array}{l}26 \text { January } \\
2022\end{array}$ & $\begin{array}{l}\text { Strategic } \\
\text { Evaluation of } \\
\text { WFP's Use of } \\
\text { Technology in } \\
\text { Constrained } \\
\text { Environments }\end{array}$ & $\begin{array}{l}\text { WFP } \\
\text { Evidence } \\
\text { (3) }\end{array}$ & $\begin{array}{l}\text { Among the findings are that the use of } \\
\text { digital technologies has increased } \\
\text { WFP's effectiveness, efficiency and } \\
\text { adaptability in constrained } \\
\text { environments, and had a general } \\
\text { positive effect for the people served by } \\
\text { WFP. However, more attention is } \\
\text { needed on protection risks and clear } \\
\text { internal and external positioning on the } \\
\text { responsible use of digital technology } \\
\text { and data. }\end{array}$ & \\
\hline
\end{tabular}




\section{Prevent}

\begin{tabular}{|c|c|c|c|c|}
\hline $\begin{array}{l}\text { Publication } \\
\text { date }\end{array}$ & Title/URL & $\begin{array}{l}\text { Author(s)/Publication/Publicati } \\
\text { on type (evidence, discourse } \\
\text { or policy/guidance) }\end{array}$ & Summary & Top \\
\hline $\begin{array}{l}\text { December } \\
2021\end{array}$ & $\begin{array}{l}\text { Early action and } \\
\text { the climate crisis: } \\
\text { could social } \\
\text { protection be a } \\
\text { game changer? }\end{array}$ & $\begin{array}{l}\text { Risk-informed Early Action } \\
\text { Partnership (REAP) } \\
\text { Evidence }\end{array}$ & $\begin{array}{l}\text { Argues that an integrated approach to } \\
\text { early action and social protection is } \\
\text { heeded to address the } \\
\text { multidimensional risks of climate } \\
\text { change. It summarises evidence on } \\
\text { the benefits, barriers and enablers to } \\
\text { early action and social protection }\end{array}$ & \\
\hline $\begin{array}{l}\text { Janaury } \\
2022\end{array}$ & $\begin{array}{l}\text { Enhancing } \\
\text { Warnings }\end{array}$ & $\begin{array}{l}\text { Carina Fearnley and Ilan } \\
\text { Kelman; UCL Warning } \\
\text { Research Centre } \\
\text { Evidence }\end{array}$ & $\begin{array}{l}\text { Report on early warning systems. } \\
\text { Focused on the UK, but with examples } \\
\text { from the rest of the world and based } \\
\text { on a broad literature review. }\end{array}$ & \\
\hline $\begin{array}{l}\text { January } \\
2022\end{array}$ & $\begin{array}{l}\text { Safeguarding } \\
\text { people living in } \\
\text { vulnerable } \\
\text { conditions in the } \\
\text { COVID-19 era } \\
\text { through universal } \\
\text { health coverage } \\
\text { and social } \\
\text { protection }\end{array}$ & $\begin{array}{l}\text { Gabriela Cuevas Barron et al.; } \\
\text { The Lancet } \\
\text { Discourse }\end{array}$ & $\begin{array}{l}\text { Recommendations for governments } \\
\text { and other actors on medium to long- } \\
\text { term strategies against Covid-19 and } \\
\text { its effect. Recommendations from the } \\
\text { Lancet Commission on COVID-19's } \\
\text { Task Force on Social Protection, } \\
\text { Humanitarian Action include } \\
\text { prioritising cash assistance and } \\
\text { working through national systems. }\end{array}$ & \\
\hline $\begin{array}{l}\text { Janaury } \\
2022\end{array}$ & $\begin{array}{l}\text { The state of } \\
\text { knowledge on } \\
\text { disaster risk }\end{array}$ & $\begin{array}{l}\text { Minh Tran and Michael } \\
\text { Boyland; IRDR working paper } \\
\text { series } \\
\text { Evidence }\end{array}$ & $\begin{array}{l}\text { A literature review on disaster risk. It } \\
\text { covers concepts such as risk, } \\
\text { resilience and vulnerability; tools used } \\
\text { in disaster risk analysis; and gaps in } \\
\text { the field. }\end{array}$ & \\
\hline $\begin{array}{l}\text { January } \\
2022\end{array}$ & $\begin{array}{l}\text { Give Peace a } \\
\text { Chance }\end{array}$ & $\begin{array}{l}\text { IASC RG4; podcast } \\
\text { Evidence }\end{array}$ & $\begin{array}{l}\text { Part of a series of podcasts on the } \\
\text { hexus. }\end{array}$ & \\
\hline $\begin{array}{l}\text { 3 January } \\
2022\end{array}$ & $\begin{array}{l}\text { Aid policy trends } \\
\text { to watch in } 2022\end{array}$ & $\begin{array}{l}\text { Jessica Alexander; The New } \\
\text { Humanitarian } \\
\text { Discourse }\end{array}$ & $\begin{array}{l}\text { Outlines four key trends for } 2022 \text { : } \\
\text { efforts to plug the funding gap; } \\
\text { increased focus on climate; the } \\
\text { decolonisation agenda; continued } \\
\text { challenges to access and } \\
\text { humanitarian principles. }\end{array}$ & \\
\hline
\end{tabular}




\begin{tabular}{|l|l|l|l|}
$\begin{array}{l}\text { November } \\
2021\end{array}$ & $\begin{array}{l}\text { Humanitarian Al } \\
\text { The hype, the } \\
\text { hope and the } \\
\text { future }\end{array}$ & $\begin{array}{l}\text { Sarah W. Spencer; ODI } \\
\text { Evidence }\end{array}$ & $\begin{array}{l}\text { Paper outlining key definitions, } \\
\text { potential benefits, barriers, and risks to } \\
\text { using Al in humanitarian action. }\end{array}$ \\
\end{tabular}

\section{Resource Hubs}

\begin{tabular}{|c|c|c|}
\hline Title/URL & Author/Organisation & Summary \\
\hline Evidence database & Anticipation Hub & $\begin{array}{l}\text { Database of evidence on the } \\
\text { effectiveness of early actions. }\end{array}$ \\
\hline $\begin{array}{l}\text { Covid-19: tracking local } \\
\text { humanitarian action and } \\
\text { complementary partnerships }\end{array}$ & $\begin{array}{l}\text { Overseas Development } \\
\text { Institute, Humanitarian Policy } \\
\text { Group }\end{array}$ & $\begin{array}{l}\text { Map of complementary partnerships } \\
\text { and local humanitarian action across } \\
\text { the globe. }\end{array}$ \\
\hline $\begin{array}{l}\text { Social protection responses to } \\
\text { compounding risks: } \\
\text { Lessons from Covid-19 and } \\
\text { climate-related disasters }\end{array}$ & $\begin{array}{l}\text { Red Cross and Red Crescent } \\
\text { Climate Centre }\end{array}$ & $\begin{array}{l}\text { A data dashboard of social protection } \\
\text { responses to covid-19, at the national } \\
\text { and international level. }\end{array}$ \\
\hline $\begin{array}{l}\text { COVID-19 Data Explorer: } \\
\text { Global Humanitarian } \\
\text { Operations }\end{array}$ & $\begin{array}{l}\text { Humanitarian Data Exchange } \\
\text { (HDX) }\end{array}$ & $\begin{array}{l}\text { World map of covid cases and various } \\
\text { vulnerability and socio-economic risk } \\
\text { factors (including vaccine rollout, food } \\
\text { security, school closures, CERF } \\
\text { allocations etc.). }\end{array}$ \\
\hline $\begin{array}{l}\text { Covid-19 and Humanitarian } \\
\text { Crises }\end{array}$ & $\begin{array}{l}\text { Johns Hopkins Center for } \\
\text { Humanitarian Health, } \\
\text { Health in Humanitarian Crises } \\
\text { Centre, London School of } \\
\text { Hygiene and Tropical Medicine } \\
\text { and Geneva Centre of } \\
\text { Humanitarian Studies, The } \\
\text { Graduate Institute of } \\
\text { International and Development } \\
\text { Studies and the University of } \\
\text { Geneva }\end{array}$ & $\begin{array}{l}\text { Website for the exchange of field- } \\
\text { based COVID-19 programme } \\
\text { adaptations and innovations. }\end{array}$ \\
\hline $\begin{array}{l}\text { Covid-19 Mobility Impact } \\
\text { Reports }\end{array}$ & UN IOM & $\begin{array}{l}\text { Frequently updated reports on } \\
\text { migration restrictions. }\end{array}$ \\
\hline $\begin{array}{l}\text { IDMC Internal Displacement } \\
\text { Updates }\end{array}$ & $\begin{array}{l}\text { Internal displacement } \\
\text { monitoring centre }\end{array}$ & Global data on internal displacement \\
\hline ACAPS Crisis in Sight & ACAPS & $\begin{array}{l}\text { Global overview of crisis, including } \\
\text { covid and conflict; as well as access } \\
\text { constraints. }\end{array}$ \\
\hline $\begin{array}{l}\text { CVA and COVID-19: } \\
\text { resources, guidance, events } \\
\text { and questions }\end{array}$ & CaLP & $\begin{array}{l}\text { Guidance and resources on covid and } \\
\text { cash transfers }\end{array}$ \\
\hline
\end{tabular}




\begin{tabular}{|c|c|c|}
\hline $\begin{array}{l}\text { IASC: COVID-19 Outbreak } \\
\text { Readiness and Response } \\
\text { guidance }\end{array}$ & $\begin{array}{l}\text { Inter-Agency Standing } \\
\text { Committee }\end{array}$ & $\begin{array}{l}\text { IASC principles and protocols adapted } \\
\text { to covid-19 }\end{array}$ \\
\hline $\begin{array}{l}\text { OCHA } \\
\text { COVID19 Resource Material }\end{array}$ & $\begin{array}{l}\text { Office for the Coordination of } \\
\text { Humanitarian Affairs }\end{array}$ & $\begin{array}{l}\text { A wide range of guidance and } \\
\text { resources from WHO, IASC, the EU, } \\
\text { IFRF and others, as well as country- } \\
\text { specific information. }\end{array}$ \\
\hline $\begin{array}{l}\text { Humanitarian Data Exchange: } \\
\text { COVID-19 Pandemic in } \\
\text { Locations with a Humanitarian } \\
\text { Response }\end{array}$ & $\begin{array}{l}\text { Humanitarian Data Exchange } \\
\text { (HDX) }\end{array}$ & $\begin{array}{l}\text { Global data on infections and deaths; } \\
\text { a list of data sets on cases and } \\
\text { prevention/mitigation measures. }\end{array}$ \\
\hline $\begin{array}{l}\text { Humanitarian Data Exchange: } \\
\text { Government Measures } \\
\text { Dataset }\end{array}$ & $\begin{array}{l}\text { Humanitarian Data Exchange } \\
\text { (HDX) }\end{array}$ & $\begin{array}{l}\text { Global data on government covid-19 } \\
\text { measures under } 5 \text { categories: Social } \\
\text { distancing; Movement restrictions; } \\
\text { Public health measures; Social and } \\
\text { economic measures; Lockdowns. }\end{array}$ \\
\hline $\begin{array}{l}\text { IEG Lesson Library: } \\
\text { Evaluative Resources and } \\
\text { Evidence to inform the } \\
\text { COVID-19 Response }\end{array}$ & $\begin{array}{l}\text { World Bank Independent } \\
\text { Evaluation Group }\end{array}$ & $\begin{array}{l}\text { A library of Evaluative Resources and } \\
\text { Evidence to inform the COVID-19 } \\
\text { Response }\end{array}$ \\
\hline $\begin{array}{l}\text { Relief Web: regional topic } \\
\text { pages for Covid-19 } \\
\text { and global topic pages }\end{array}$ & Relief Web & $\begin{array}{l}\text { Regional and global reports and } \\
\text { resources on humanitarian needs and } \\
\text { response. }\end{array}$ \\
\hline $\begin{array}{l}\text { IASC Accountability and } \\
\text { Inclusion Resources Portal }\end{array}$ & $\begin{array}{l}\text { Inter-Agency Standing } \\
\text { Committee }\end{array}$ & $\begin{array}{l}\text { A library of resources on accountability } \\
\text { and inclusion. }\end{array}$ \\
\hline $\begin{array}{l}\text { Attacked and Threatened: } \\
\text { Health care targeted in conflict } \\
\text { and COVID-19 }\end{array}$ & Insecurity Insight & $\begin{array}{l}\text { Map of violence and threats against } \\
\text { health care across the world. }\end{array}$ \\
\hline Conflict and Health & Conflict and Health & $\begin{array}{l}\text { Open-access journal on the health } \\
\text { impacts of conflict. }\end{array}$ \\
\hline $\begin{array}{l}\text { International Journal of } \\
\text { Disaster Risk Reduction }\end{array}$ & $\begin{array}{l}\text { International Journal of } \\
\text { Disaster Risk Reduction }\end{array}$ & An interdisciplinary journal of DRR. \\
\hline Journal of Refugee Studies & Journal of Refugee Studies & $\begin{array}{l}\text { Research on forced migration and } \\
\text { responses to it. }\end{array}$ \\
\hline Disasters & Disasters & $\begin{array}{l}\text { Focuses on disaster management and } \\
\text { policy from academic and field } \\
\text { perspectives. }\end{array}$ \\
\hline $\begin{array}{l}\text { International Review of the } \\
\text { Red Cross }\end{array}$ & $\begin{array}{l}\text { International Review of the } \\
\text { Red Cross }\end{array}$ & $\begin{array}{l}\text { Journal focusing on international } \\
\text { humanitarian law, policy and action in } \\
\text { situations of conflict. }\end{array}$ \\
\hline
\end{tabular}

\section{Methodology:}

Given the wide range of topics covered, this monthly summary includes guidelines, blogs, news articles, dashboards, data, and editorials, in addition to policy and academic literature. Resources are selected based on their relevance to the themes of protect, prioritise and prevent. Entries are categorised as evidence (academic peer-reviewed articles or reports that have gone through a quality assurance process); discourse (opinion and discussion of key issues in the humanitarian sector); and policies and guidelines (newly published policies and guidelines on humanitarian response). The sources included are found through searches of academic literature, humanitarian think tanks, resource hubs and NGO websites. The searches are restricted to articles published in the previous month, in English. This is complemented by email recommendations from FCDO advisors and leading experts. It is the result of 1 day of work per month and is not intended to be a comprehensive summary of 
available evidence on humanitarian action but aims to make original documents easily accessible to decisionmakers. This is trial and error approach, which will be refined and changed over the coming weeks. If you have literature to include in the weekly summary, please email - luke.kelly@manchester.ac.uk.

\section{Suggested Citation}

Kelly, L. (2021). Humanitarian evidence and discourse summary No.23. K4D Helpdesk Report. Brighton, UK: Institute of Development Studies, DOI: 10.19088/K4D.2022.014

\section{About this report:}

The monthly Humanitarian Evidence Summaries are not intended to replace professional advice and the researcher or the K4D consortium cannot be held responsible for any decisions made on the basis of the summaries alone.

K4D services are provided by a consortium of leading organisations working in international development, led by the Institute of Development Studies (IDS), with Education Development Trust, Itad, University of Leeds Nuffield Centre for International Health and Development, Liverpool School of Tropical Medicine (LSTM), University of Birmingham International Development Department (IDD) and the University of Manchester Humanitarian and Conflict Response Institute (HCRI).

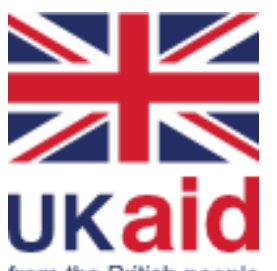

from the British people

This evidence summary was prepared for the UK Government's Foreign, Commonwealth and Development Office (FCDO) and its partners in support of pro-poor programmes. It is licensed for non-commercial purposes only.

K4D cannot be held responsible for errors, omissions or any consequences arising from the use of information contained in this health evidence summary. Any views and opinions expressed do not necessarily reflect those of FCDO, K4D or any other contributing organisation.

(C) FCDO - Crown copyright 2021 